\title{
The Analysis of Marxist Philosophy in Ajmal Khattak's Poem "Faisla" (Decision): A Critical Discourse Study
}

Bibi R*

Bahauddin Zikriya University, Multan, Pakistan

*Corresponding author: Bibi R, Bahauddin Zikriya University, Multan, Pakistan, Tel: 92619210097; E-mail: robeenakhaliq@gmail.com

Received date: September 22, 2015, Accepted date: October 29, 2015, Published date: November 3, 2015

Copyright: (c) 2015 Bibi R. This is an open-access article distributed under the terms of the Creative Commons Attribution License, which permits unrestricted use, distribution, and reproduction in any medium, provided the original author and source are credited.

\begin{abstract}
This paper attempts to explore the influence of Marxist thought on modern Pashto poetry. Ajmal Khattak, a revolutionary and progressive Pashto poet of the 20th century, wrote under the influence of Marxism. This study analyzes the Marxist ideology in Ajmal Khattak's poem Faisla (Decision) using Fairclough's three dimensional model of Text, Discourse practices and Social practices. In order to uncover the Marxist ideology of the poem special attention is given to the style, tone, theme and the choice of words. Though Khattak does not directly praise Marxist view in his poetry but he has used Marxist thinking to find a solution for social injustices.
\end{abstract}

Keywords: Marxism; Critical discourse analysis; Ideology; Pashto poetry

\section{Introduction}

Ajmal Khattak is one of the most popular nationalist and revolutionary poets among the modern Pashto poets. He was born in Akora Khttak on 15 September, 1925. He recited his first poem at the age of 13 . He joined the freedom struggle and began his political career during the Quit India Movement. He left his school because of being involved in political activities. Khattak joined the Khudai Khidmatgar (Servants of God). Led by Bach khan this movement was an outstanding effort to generate social, national and political consciousness to redefine Pukhtoonwali. The basic principles of this movement were non-violence and service to the people regardless of faith, race and language. This movement joined Indian National Congress to confront the against British rule in India. He was the member of Awami National Party. He became Member of National Assembly in 1990. He also remained senator [1].

Apart from being a committed political worker with staunch political convictions, Ajmal Khattak was literary man as well. He wrote about nationalism, social problems. He published many books of prose and poetry in Pashto as well as in Urdu. His famous writing include: Da Ghairat Chagha, was published in 1958, that was later banned in Pakistan and Afghanistan. A history of Pashto Literature", "Pakistan Main Qaumi Jamhoori Tehreekain", "Batoor", "GulParhar", Guloona Takaloona", Jalawatan kee Shairee", Pukhtana shora", "Da Afghan Nang" and " Da Wakht Chagha". He set a different poetic tone than his traditional contemporary poets. His poetry is a blend of beauty of human nature and courage of a revolutionary.

Through his works Khattak voiced the voiceless anguish of the subdued human dignity. The ideologies Ajmal Khattak explores in his works are Pukhtoonwali and nationalism and criticism upon the social structure. In most of his poems he criticized the way power and wealth are distributed in society. Poems like "Da Nawab Saib Mekhi" and "Olas Ta" have the same theme of unequal social structure and the dehumanized state of common man is addressed.
The present study focuses on one of Khattak' poem entitled as "Faisala"(Decision) and analyzes it from Marxist perspective using Critical Discourse Analysis as tool. The study focuses selected verses from the poem to find out how Ajmal Khattak expresses his Marxist view of society in the present poem by the use of lexical choices, tone and style.

\section{Theoretical Framework}

\section{Marxism}

Marxist school of thought was founded by two thinkers i.e. Karl Marx (1818-1883) who was a German philosopher and in the words of Dalahoyde "Karl Marx was primarily a theorist and historian" and Friedrich Engels (1820-1895), a German sociologist. Marx applying a scientific approach observed the social structure throughout history and perceived that human history had been comprised of a sequence of conflicts between oppressors and the oppressed classes. The conflict is caused by the difference in the social classes. Birch points out, "a Marxist position grounds social reality in a history, struggles centered upon class and systems of production, reflecting at any given moment a dialectical relationship between history and society." The social reality that is 'centered upon class and system of production' is, as Palmer points, determined by an 'underlying structure' and in order to understand the social reality that underlying structure should be grasped. The underlying structure, for Marx, is the economy the foundation of which is rooted in natural resources, the sources of production and distribution, grounded on two theoretical concepts that are 'Base structure' and 'Superstructure. Base structure refers to the means of production (machines, tools, raw material, land etc.) and relation of production (the laborers, their roles and relationship and the materials and sources involved in the production) Superstructure, quite simply and expansively, refers to all other aspects of society. Superstructure includes ideology, culture, values, beliefs, norms, social institutions (education, religion, media, and family), the political structure and the State. Marx contended that the Base determines the superstructure but the base is influenced by the superstructure as it reflects the interests of the ruling class hence justifying that the base is operated by the power of the ruling class. 
This economic structure establishes the position of oppressed and oppressor classes. The oppressors exploit the labor class for creating more wealth. However, the labor class has no influence over the distribution of the wealth they produce. In order to maintain the status quo and to make the people accepted the way things are, the oppressor class gives rise to ideology which is operated by the Ideological State Apparatuses (Family, culture, religion, education, political system and media) as pointed out by Althusser which results into static, partial and one sided notions that reflect only what the capitalists want everyone to think controlling the way people think.

\section{Critical Discourse Analysis}

Critical Discourse Analysis (CDA) should be taken as both a theory and a method as it suggests 'not only a description and interpretation of discourses in social context but also offers an explanation of why and how discourses work'

CDA looks at a text as piece of art that does not take place in isolation. The analysis and interpretation of a text is carried out on the basis of the socio-economic, socio-political and socio-historic contexts. CDA can be seen as a 'highly context-sensitive, democratic approach which takes an ethical stance on social issues with the aim of transforming society - an approach or attitude rather than a step by step method'. The basic notion of CDA is that there is asymmetrical access to social and linguistic resources. The resources are controlled by institutions. Therefore CDA is primarily concerned with institutional discourses - policy, media, labeling gender, etc.

When a discourse develop into dominant enough that the alternative interpretations are completely suppressed or avoided, then it stops to be looking as arbitrary and is viewed as natural, and a legitimate way because that is 'the way things are'. This process is referred to as "naturalization" by Fairclough [2] through which a 'Naturalized' discourse loses its ideological quality and seems to be neutral thus representing its 'story' as 'truth'.

CDA analyzes "opaque as well as transparent structural relationships of dominance, discrimination, power and control as manifested in language". CDA wages war against the exploitation and supports the exploited ones by sensitizing them to towards the prevalent situation. CDA aims to make the discourse more transparent because discourse is s an "opaque power object in modern societies"

Fairclough and Graham [3] talked about Karl Marx's works in which Marx established that ideas do not exist separately from language. Talking about three conceptual elements: Abstraction, Dialectics and ideology, which are central to understand the discursive aspects of Marx's critical method, they found that Marx was a naturalist and humanist who followed discursive approach to analyze social phenomena. Though discourse analysis did not exist in his time but his view and mode of language critique are similar to what we call critical Discourse Analysis today. He used language as a tool to criticize capitalism. Fairclough and graham [3] believe that Marx to be a critical discourse analyst by giving reference to his text. The objective was to show how Marx applied language critique to the capitalist order of his day.

According to Fairclough and Graham [3] "Critical language analysis is central to Marx's method precisely because language is the only way we have of grasping the diachronics of changing social circumstances not language as an abstract system of signs, but as a mutually determining product and substance of changing material circumstances and practices; not as the abstract representative of externalized ideas, but as both product, producer, and reproducer of social consciousness, which in turn is in a reciprocally causal relationship with the whole of the human experience. In these very important respects, Marx's method and the methods of CDA are identical". (Marx as a Critical Discourse Analyst: The genesis of a critical method and its relevance to the critique of global capital).

CDA methods analyze the linguistic forms to unravel the social and economic conditions which are built upon exploitation and dehumanization of some by some others. In Marxist thought language is a social process which is dialectically connected with other walks of life.

Capitalism, according to Marx, is a discourse that is the offspring of ideology language and discursive practices and it should be resisted in the same way as it is constructed.

CDA is not only a linguistic but a framework for analyzing ideologies in discourse as Van Dijk [4] points out, "CDA does not have a unitary theoretical framework or modeling". CDA, unlike discourse analysis, has its major thrust, i.e., the necessity that social and economic resources should ordinarily usher in the desired sociopolitical and economic prosperity. Fanon (as cited in Wilmot) [5] urged the masses to speak out because "The future would have no pity for those men, who possessing the exceptional privilege of being able to speak words of truth to their oppressors, have taken refuge in an attitude of passing, of mute indifference and sometimes of cold complicity".

\section{Social consciousness}

The notion of consciousness permeates through the poem "Faisala" (Decision). Ajmal Khattak seems to be engaged in the creation of idea to suggest the adoption of ideology particularly. He tries to elucidate the crucial relation between the ideal and reality. The common thread in all verses of the poem is his efforts to sensitize the common man and to mobilize them against the form of governance in Pakistan in particular, and Asia as a whole. The underlying themes of the poem are the cut-throat exploitative tendencies of the elite class who represents being the dominant in the society leads the nation to their present state of anomie, the clash of ideology between the elite and the one that Khattak and other intellectuals present, the spirit of revolution and the decision he takes at the end of the poem.

Faisala reflects the decadence of many Asian nations, arising from misrule, voracious greed and corruption in all facets of life. The poem begins with a direct address to an assumed addressee who belongs to the Elite class. Khattak begins with:

\section{sta da"khan kaka" pa kor kizar ambar v}

Your rich uncle house in gold pile is

(Your rich man's house is piled with gold)

aao zama bachidi khawri satikhwar $\mathrm{v}$

And my children will mud suck poor is

(And my children will suck (eat) mud as they are poor)

sta bankona kho di wraz pa wraz parsegi,

Your banks let day by day swollen

(Let your bank accounts are swollen (with money) day by day) 
ao zama vena didrang pa drang ochegi

And my blood let time to time dry

(And let my blood be dried time to time)

Wazday weele pa patokime zama she

Fats melton fieldsinmybe

(My fats melt in the fields)

Tre na jora sta bangle ki sta ranra she

From make your banglow in your light be

(From that the light is produced in your banglow)

tazamapagataaishkawi jwanday ye,

You my on profit debauchery do live is

(You do debauchery and live on my profit)

zada sta qarzoki gharq warsham gorta

I your debts in doomed go grave to

(I reach to grave doomed by your debts)

tazama haqda pradaidami inamkri,

You my right of stranger dancer prize do

(You give my right to stranger dancer in prize)

za marrai warkaway na sham khpali morta

I morsel to give not can my mother to

(I cannot give a morsel to my mother (for eating))

Throughout there is a comparison between the condition of elite and the working class. the condition of rich is shown through the images like "their houses piled with gold", their banks swollen with money", "the lights in their big banglows", the comfort of their lives", while the condition of working class is indicated through the use of images like: "their children eat mud", "their blood drying", "their fats melting due to hard work", "deprivation of their rights", "less food for their family".

The poets addresses the system directly and explain the plight of the poor man who works hard and melts his fats in the fields but his family has always been having not enough food. Though the wealth and comfort that the rich enjoy is the offspring of the poor working men's blood, yet they remain deprived of their share in the wealth.

The use of the words like khawre sati "suck/eat mud", wena ochegi "blood drying", wazday weely "fats melting", sta qarzo ki gharq, "doomed in your debt" and marrai warkaway nasham "cannot provide a morsel", draws the attention to the social condition of the masses who are suffering because of their low socio-economic place. On the other hand the words used for the elite class like, zar anbar , "gold piled", bankona parrsegi, " bank are swelling(with money)", bangle ki ranra, "light in banglow" and aish kawe, "live luxuriously", indicate how they exploit the labors for their own comfort and status. The lexical choices for the comparison of the social condition of both high and labor class explains how the system sucks the blood of the poor while giving nothing in return. It also indicates that very often the existence of this labor class is threatened by poverty.

The above verses illustrate the state of laborers and landlords in the country which is clear description of class difference where rich people, not only capitalist but feudalist class, is represented who have full stomach and the lower class live his life in huger and dearth. It can also be understood that the circulation of wealth is uneven thus workers strip their belly and landlords take benefits without doing any hard work.

ta zama khona ki humzama malak ye,

You myhouse in as wellmyownerare

(You are the owner of my house)

za khpal kor ki hum sta stargo kidarghal yam

I mine house in as well your eyes in fraudulentam

(In my house you consider me as fraudulent)

ta ka taki tori wayi hum tak speen ye,

You if very black say also very white are

(Your false words are also taken as truth)

za ka speeni speeni wayam gunahgar sham

I if white white says inner become

(If I say truth, I become a sinner)

Ta ka tol na haq na haq kawi aqaye,

You I fall undeserved do master are

(If you do undeserved things, you can because you are master)

za ka haqchariowayama padar sham

I if truth any day say on gallows

da manama che nan sta da zorkhanida,

This I agree thattodayyourof powerrichnessis

(I agree that today you are powerful because you are rich)

damanama har sa sta di ma ba khwar ki

This I agree all things yours I will poor make

(I agree that all things are yours and I will make me poor)

The above eight verses paint the horrid picture of the Justice system which is truly an Injustice system for the poor. Khattak bluntly satirizes the so called justice system that though the rich man's sayings and doings are black and crime but still his position makes him innocent and justified. On the other hand, a poor man's true statement is considered as false. Khattak satirizes the state's injustices against the poor masses. They cannot buy justice for themselves. But still he is speaking to unravel their true faces to the masses. According to Althusser in Marxist tradition the state is a "Repressive State Apparatus". The State is a 'machine' of repression, which enables the ruling classes (in the nineteenth century the bourgeois class and the 'class' of big landowners) to ensure their domination over the working class, thus enabling the former to subject the latter to the process of surplus-value extortion (i.e. to capitalist exploitation).

The state practices its power through different institutions like police, legal and judiciary system, courts prisons and army. Therefore, Althusser has termed these institutions as Repressive State Apparatuses which " defines the State as a force of repressive execution and intervention 'in the interests of the ruling classes' in the class struggle 
conducted by the bourgeoisie and its allies against the proletariat, is quite certainly the State, and quite certainly defines its basic 'function."

Lexical choices for the landlord and for himself for example, "Aaqa" and "malak" (master) for the landlord and "ghal" (thief) and "darghal" (fraudulent) for himself shows that the ideology has interpolated and because of this he is accepted as the owner and master and those who produce are "ghal" and "darghal". This situation is accepted without any challenge by the masses.

\section{Self-realization}

The poet seems to be realizing the standpoints of both of the social classes. He expresses his understanding of the standpoints of the high and the low classes in the upcoming verses. He says:

Da manam che sta na bazan wrak e

This accept that you from self-lost be

(I accept that you are lost in your pride)

Kho ma opejana mata hum ogora

But I know to me as well look

(But know me, look at me)

Dasta zar sa dy? Bachy meda mehnatdy

This your wealth what is child mine of hard work is

(Your wealth is the child of my hard work)

Aostazor?Zama da matobarakat dy

And your strength? My of arms benediction is

(And your strength is the benediction of my arms)

Aoda ta sa e zama da lasojor e

And this you what is my of hands made

(And what are you? (You are) made up of my hands)

Daza ogyyamta zakadumramorre

This I hungry am you because this much wealthy are

(You are wealthy because I am hungry)

Ma da sara odangal nu watan jor sho

I from head jumped so then state make was

(I put my life at stake and then this state was made)

Ma khwari okra nu hala chaman jor sho

I hard work did so then garden make was

(I did hard work and then this garden was made)

Ma aghyar wrak kra nu hala ta dildar shwe

I rivals lost did so then you dear become

(I defeated the rivals then you became dear (to people))

Ma che sar sar kronu hala ta sardar shwe

I head (put at stak in fight) did so then you leader become

(Sacrificed my head so then you became the leader)

Ma makan jor ko nu hala ta makeen shwe
I house make did so then you resident become

(I made the house so then you became the resident)

Ma takht jorko nu hala ta takht naseen shwe

I throne make did so then you enthroned become

(I made the throne so then $\mathrm{u}$ became enthroned)

Pa depoha sha cheza yama zaka ta e

On this understand that I am that's why you are

(Understand this facet that you are you because of me)

Ka za nasht shumta la sok e che ba shta she

If I not existence become you who are that will exist

(If I exist no more who are you to exist) their existence is dependent

The theme echoed throughout in these lines is that of selfrealization in a tone capable of winning sympathy for the oppressed. He tries to catch the attention of the elite class by saying that there excessive pride makes them unable to look at their position and the position of the working class. He explains by asking rhetorical questions from the elite class that the position, wealth and strength of the high class are not something that is bestowed upon them, or they have acquired it by their own. As compared to the previous verses where the tone is that of complaint and agony. In these verses the tone is turned harsh. By asking rhetorical questions he establishes his point of view that the elite class is elite class because of struggle of the poor. Verses 23 to 28 are contextualized into the historical event of getting freedom from both Hindues and Britishers, whom he refers to as "Aghyar" (rivals)and to establish a separate country for the Muslims. The Movement of Pakistan was made successful by paying the lives of hundreds of Muslims. He counts the efforts of the laborers in establishing the state by saying that this state is the offspring of their sacrifices. He uses the symbols of "chaman" (garden). "watan" (country), "makan"(home) and "takht" (throne) for the state for which the masses put their lives at stake but in the same state they are deprived of what they need. The sacrifices of the common man hailed the names of the political leaders and now the world recognize and remember only the leaders and stat men while the common man's suffering $s$ and sacrifices are not visible to anyone.

Through the use of symbols, powerful imagery, appropriate style and lexical choices, the poet depicts a bitter reality of the social and political system.

The last two verses are the most striking examples of self-realization. The poet establishes his notion by saying that the existence of the prestigious class is because of the existence of the poor class. If the poor class is no more there, there would be no elite class existing.

These verses indicate that the ideology which is termed as "false consciousness" by Karl Marx and which is interpolated by the Elite class over the working class for their interest has now taken a turn and will bounce back upon the Elite class because he is letting working class now knows their position and the position of their so called masters. Since the ruling class is interpolated by the ideology they created for the working class, now the working class after realizing their strength is capable to trigger a move against the ruling class and their injustices to them.

Ta namos lote, haya akhlijwand khwar kre

You honour loot modestytake, lifeimpoverished 
(You loot modesty and is impoverished by your life)

Da sharabo pa numskhi da khwaro wena

Of wine on name drink of poorsblood

(You drink the blood of the poors on the name of wine)

Tazama da mehnat ghal dafan daako e

You my of hard work theif buried robber is

You are the theif of my hard work and a buried (unknown) robber

Skizama da wene khati sharabona

Drink myof blood made wines

((You) drink the wine made up of my blood)

Khattak ruminates over a wide range of issues such as man's inhumanity to man and that the path of corruption and social decay has led to moral degeneration.

These lines indicate the system of exploitation through the repeated imagery of wine which is drawn from the blood of the exploited. Khattak paints the picture of a diseased society represented by the image of looters who plunder the workers' production, but even being the "mehnat ghal" (thief of hard work) these robbers are "dafan" (buried) which means that whatever they do, these people remain hidden from the others' eyes. The image of sucking their blood which has turned into wine connotes that prestigious class constitute parasites to others. Khattak satirizes the way in which the elite class who has become an exploitative class.

The elite class forms the basis of neo-colonialism by accumulating excessive wealth without any visible sign of productive potentials.

The poet highlights their cruel plundering of nation's resources. He investigates the roots and several varieties of the unidentified manipulative, unequal and repressive system.

Lexical choice plays an important role in illustrating different images of 'agony', doom' and 'pain. For example the verses "da sharabo pa numski da khwaro wena" (you drink the blood of poor in the name of wine) and" ski zama da weno khati sharabona"( you drink wine drawn from our blood).

\section{Clash of ideology}

Khattak, being an intellectual poet tries to puncture existing ideology by presenting his ideology which is completely in contrast to the ideology of the bourgeoisie class. His ideology is voiced of the proletariat class.

Za waimtol insanyatdewrorwali she

I say whole mankind may brotherhood be

(I say the whole mankind may turn into brotherhood)

Da dunya de yao zango da khushalae she

This world may one cradle of happiness be

(This world may become the cradle of happiness)

Zor de wrak she jwand de tol khpal wali she

Power may lost be life may whole kinship be

(The power (concept) may lost and the whole life may turn into kinship)
Da narrae de khwey ao da khushalae she

This region may beautifull and of happiness become

(This region nay become beautifull and full of happiness)

Ta way "har sa"ao da "har cha" de zama she

You say everything and of everyone may mine become

(You think that everything that belong to others may become mine)

Ka "zama nashi nu " har sa" de taba she

If mine not become then everything may destroyed be

(If everything is not mine then it may destroy)

The poet expresses his wish for the liberty which is the main theme of Marxist thinking. By expressing his wishes like "insanyat" (mankind) may turn into "wrorwali" (brotherhood) and the world which he wish to become "zango da khushlae" (cradle of happiness), establishes his philanthropist view. His wish for a society and region where no one is forced, everyone is free is indication to a Marxist and CDA principle called, "Free the minds" according to which the minds of the people should always be prepared through knowledge and relevant ideologies which are needed to defy the corruption of institutions. In contrast to his utopian wishes, the dreadful wish of the elite class is also presented. They want "har sa" (everything) for themselves and if not, then they everything to be destroyed which is a misanthropist viewpoint.

\section{Decision}

Bs zama lara juda da sta juda da

Enough mine way separate is yours separate is

(This is enough Mine and yours ways are separate)

Faisaladapata na da barmala da

Decision this hidden not is obvious is

(This decision is not hidden rather obvious)

The self-realization has led the poet to announce the final decision that there ways is now separate and that the "Faisala" (the decision) is obvious and clear. This decision is a challenge to defy the exploitative powers in favor of the lower class. Moreover, this decision shows the adventurous spirit of initiating a struggle for freedom from the mental and physical slavery of the poor and to put an end to the cruelty of high class. This decision leads the poet to revolt against the prevalent system and he decides to call the people to join hands with him in the revolution for change. Khattak's call goes as:

\section{Revolution}

Tol khwaran pa yawa chagha paraoma

All poors on one cry

(All the poors through one cry)

Shaeran ao fankara baidaraoma

Poets and artists make awake

I am awaking poets and artists

Nangyali ao ghairatyanralarrzaoma 
Fighters and honrables to awake

(I awake those who fight for honor)

Khwari kakh ghayorinsan rawekhaoma

Hard worker honorable humanamawaking

(I am awakening hardworking and honorable human)

Da Asia da zrra arman pora kaoma

Of Asiaofheart wishfulfillam doing

(I am fulfilling Asia's heart's desire)

Bs dy tol olas afghan rakhabraoma

Enoughis allnationAfghan to let know

This is enough, now I will let all the Afghans know ( the reality))

Da khpal haq ao da marampa num yao kigo

Of own right and of purpose of name one become.

(Let's become one for our right and purpose)

Har che kigi rawanigo rawanigo

(Whatever comes, we will proceed).

In the whole poem the poet challenges the status-quo directly and stands as a revolutionary for the cause of right till the last. Since the poor are left desolate and in dreadful condition without any hope of productive fulfillment, the need for avant-garde transformation of the society and for the unvoiced to throw away complacence in order to be heard. Through the pathos and emotive powers of his verse, the poet instigates the exploited masses into revolutionary protest. He calls people from different walks of life like "shaeran ao fankaran" (poets and artists) as they are sensitive people and can understand the prevalent situation in a better way so they can propagate his message to the common people, "Nangyali ao ghairatyan" (fighters) for fighting to snatch their rights, Khwari kakh (hard workers) so that they can know the importance of their labor and "tol olas afghan"(the whole Afghan Nation) the whole Pakhtoon nation.

The last lines indicate an optimistic approach for changing the situation of not only the state but of the whole Asia by getting rid of the vindictiveness and exploitation which is one of the basic notions of Marxism. In Marxism the revolt and standing against the status quo is basic notion because the status-quo is set up by the upper class with a selfish motive they would never confer any good to the labor class thus keeping them downtrodden and in suppression throughout the history.

The poem is spontaneous urge to initiate a revolution showing and the suggestion of not ceasing it no matter what happens is very enthusiastic. In twentieth century these sort of revolutionary slogan were heard which were the mainstream philosophy of that age [6].
In the above lines there is the clear concept of challenging authority and facing such difficulties which show the Marxist approach in his vision and thought. Because according to Khattak reflects the Marxist ideology that the marginalized group of lower class will incur the pioneering steps initially to liberate themselves. This pioneering step of the marginalized social class can prove a social rebirth if people like artists, intellectuals, hard workers and fighters come to forth and take the lead of the society. They last words "rawanigo rawanigo" lay emphasis on the collective efforts to re-establish the system of justice and equality.

Khattak seems to be a symbol of hope and a Marxism proponent inspiring all others with his scholarly thought to fight against the unrightfully domination of the elite class.

\section{Conclusion}

Literature and language prove to be valuable instruments for effective positive changes in societies. Pashto literature like all other literatures of the world contains universal thoughts and deep intellectual properties.

To conclude it can verily be said that Ajmal Khattak was not only immersed in the Marxist thought but also prove himself to be a revolutionary poet of the age thorough his poetry. Through this poem, the plight of ordinary people who have no means of decent livelihood is brought to forth. He tries to find the salvation of the inappropriate distribution of wealth and material goods and social injustices from the perspective of Marxism and as a result propose to challenge the statusquo by carrying out a revolution to transform the country on the whole. He wants to establish the society based on Marxist principles/

Moreover, this poem has proved to be the strongest inspirational content for bringing change in society which is an important factor to establish nationalism.

\section{References}

1. (1990) Ajmal leaves behind treasure of poetry, prose. University book agency peshwar.

2. Fairclough N (2000) Language and power (2nd edn) Critical Discourse Analysis An analytic framework for educational research, Longman, New York.

3. Fairclough N, Graham P (2002) Marx as a critical Discourse analyst: The genesis of a critical method and its relevance to the critique of global capital. Estudiosde Sociolinguistica 3: 185-229.

4. Van Dijk T (2000) Critical discourse analysis.

5. Wilmot P (1986) Ideology and national consciousness. Lantern Books Ltd, Ibadan.

6. Blunden A (1970) Lenin and Philosophy and Other Essays Translated. Monthly Review Press. 